\title{
The Impact of IFRS Adoption on Earnings Quality: A Study Conducted on Foreign Issuers in the United States
}

\author{
Priscilla Samantha den Besten ${ }^{1}$, Georgios Georgakopoulos ${ }^{2}$, Konstantinos Z. Vasileiou ${ }^{3} \&$ Nikolaos Ereiotis ${ }^{4}$ \\ ${ }^{1}$ Amsterdam Business School, University of Amsterdam, Netherlands \\ ${ }^{2}$ Department of Accounting \& Finance, University of Strathclyde, UK \\ ${ }^{3}$ Department of Business Administration, TEI of Western Greece, Greece \\ ${ }^{4}$ Department of Economic Sciences, National and Capodistrian University of Athens, Athens \\ Correspondence: Georgios Georgakopoulos, Senior Lecturer of Accounting, University of Strathclyde Business \\ School, Department of Accounting and Finance, Curran Building Level 3, Room 3.59, 100 Cathedral Street, \\ Glasgow G4 0LN, Scotland. E-mail: georgios.georgakopoulos@ strath.ac.uk
}

Received: June 17, 2015

doi:10.5539/ibr.v8n11p139
Accepted: June 27, 2015

Online Published: November 26, 2015

\begin{abstract}
The worldwide adoption of International Financial Reporting Standards (IFRS) is affecting many countries around the globe as it has become widely spread. Since 2007 the United States (US) allows foreign issuers to voluntarily adopt IFRS. This paper investigates the effect of IFRS adoption on earnings quality after voluntary IFRS adoption was allowed to foreign issuers in the US. More precisely, the discretionary accruals and the small positive earnings are tested for a sample of foreign issuers in the US that are registered and reporting with the SEC, comparing a pre-period from 2002 to 2006 with a post-period from 2008 to 2011. The results from the difference-in-differences regression analysis suggest that in terms of discretionary accruals there is no statistical difference between the pre-IFRS and the post-IFRS period, therefore the earnings quality remains the same. For small positive earnings it is found that, when foreign issuers incorporate IFRS, these are lower, indicating higher earnings quality.
\end{abstract}

Keywords: IFRS, United States, earnings quality, discretionary accruals, small positive earnings

\section{Introduction}

In recent years the number of companies in the world adopting International Financial Reporting Standards (IFRS) as their main financial reporting standards has rapidly increased (AICPA, 2012). Thus, worldwide many companies have started either mandatory or voluntary the IFRS adoption or have initiated the process towards IFRS. The number of companies increased even further when in 2005, the European Union (EU), Australia, South-Africa and Turkey introduced mandatory IFRS adoption for all publicly listed companies. Nowadays, over 120 countries are permitting or requiring IFRS for their publicly listed companies and this number is continuously increasing (IASPlus, 2012; PWC, 2012).

The United States (US) is one of those countries that have started the process towards replacing their domestic reporting standards, the US Generally Accepted Accounting Principles (US GAAP), for IFRS. Since the US Securities and Exchange Commission (SEC) released a roadmap for IFRS adoption in the US in 2008, an intensive debate amongst advocates and opponents of IFRS followed (Hail et al., 2010). Although the US SEC had planned to make the final decision on IFRS adoption in 2011 accordingly to their roadmap for all publicly listed companies, they failed to do so. Therefore, the debate about a possible mandatory IFRS adoption is now still going on in the US (AICPA, 2012; IASPlus, 2012; SEC, 2012).

On the one hand, advocates for IFRS adoption find that incorporating IFRS as main financial reporting standards for instance increases overall accounting quality, results in higher comparability, transparency and availability of financial information amongst different countries and thus, it is beneficial for global investments (Ball, 2006; Armstrong et al., 2008; Jeanjean \& Stolowy, 2008; Hail et al., 2010). On the other hand, the opponents argue about the complexity of IFRS, they claim that it is associated to lower reliability of financial reporting and that it results in problems of harmonization (Armstrong et al., 2008; Jermakowicz \& Gornik-Tomaszewski, 2006; Soderstrom \& Sun, 2007; Hail et al., 2010). They find that benefits do not outweigh the consequences and high 
transaction costs that IFRS implies. Furthermore, factors that are fairly important to consider when comparing the implementation effects of IFRS adoption amongst different countries are country specific factors, such as economic, political, regional, quality of legal enforcement and interpretation differences and as well as institutional and firm-specific characteristics (Ali \& Hwang, 2000; Burgstahler et al., 2006; Jermakowicz \& Gornik-Tomaszewski, 2006; Chytis et al., 2013; Chytis, 2015). These factors cause differences in the consequences of IFRS adoption, when comparing amongst different countries.

As the process towards making a decision about IFRS adoption for all publicly listed companies is continuing in the US, the SEC approved a new reconciliation rule earlier on November 15, 2007, which allowed foreign issuers in the US to file in accordance with IFRS and thus without reconciliation to US GAAP (Cascini \& Rich, 2008; Yu, 2011; Sun et al., 2011; Sridharan \& Soonawalla, 2011). On March 4, 2008, this new reconciliation rule (hereafter, called IFRS adoption) started to apply, whereas voluntary IFRS adoption for foreign issuers in the US was introduced (Yu, 2011).

This paper contributes to the debate of IFRS adoption in the US of whether IFRS can truly be seen as uniform high-quality reporting standards, specifically by investigating the effect on discretionary accruals, therefore earnings quality. More precisely, the association between IFRS after the new reconciliation rule became effective for foreign issuers and discretionary accruals will be tested in a pre-IFRS time period and a post-IFRS time period. The research question is: Does IFRS adoption increase earnings quality, specifically accruals quality for foreign issuers in the US after IFRS adoption from 2007 onwards?

In order to address this research question, earnings quality for foreign issuers in the US will be tested by using two earnings attributes, i.e. the absolute value of discretionary accruals and the small positive earnings. The research sample contains foreign issuers in the US registered and reporting with the SEC in December 31, 2011 (US SEC, 2012). Moreover, these firms file a 20-F form, whereas their companies' information is more reliable for this research, as these firms are required to meet certain disclosure requirements (Sridharan \& Soonawalla, 2011). The applicable time interval period includes all data that are available for the pre-IFRS adoption period from 2002 to 2006 and the post-IFRS adoption period from 2008 to 2011. The findings emanate from the comparison between the two time intervals, and foreign issuers in the US that are users of IFRS in the post-IFRS period and the non-IFRS users in the pre-IFRS period.

The contribution of this paper is to provide evidence on IFRS that is applicable in the specific US context. Findings from prior research provide insights on the effect of IFRS adoption in the world, but differences can be observed across countries. Many arguments lack in their generalizability, when it comes to applying the consequences to different countries, due to their dependence on country specific and institutional factors (Burgstahler et al., 2006; Sun et al., 2011). Thus, prior research is unable to guarantee the same results for the US Conducting research in a US context can be useful to the current debate on mandatory IFRS adoption for all publicly listed companies in the US and contribute to the decision-making of the US for joining the rest of the world in their implementation of a single set of high quality uniform reporting standards. By examining the association between earnings quality and IFRS adoption of foreign issuers in the US, this paper provides practical implications of IFRS in the US context. Also, due to the time interval most recent and reliable information can be obtained.

The outline of this paper is structured as follow: Next section deals with the literature review in relation to IFRS and its adoption in the US, and the consequences of IFRS adoption. The research hypotheses, methodology and data sample are then presented. This is followed by our research results. Our paper concludes with a discussion of our findings, limitations of our work and areas for future research.

\section{Literature Review}

\subsection{A Worldwide Uniform Reporting Language}

In recent years the convergence of domestic standards with IFRS and the mandatory as well as the voluntary adoption of IFRS has become a widely discussed topic for accounting practices that affect many countries in the world. First of all, convergence of two standards implies the elimination of differences between them in order to develop a middle ground towards high quality uniform reporting standards (Pacter, 2005). The Financial Accounting Standards Board (FASB) and the International Accounting Standards Board (IASB) have started their convergence process between US GAAP and IFRS in 2002, when they agreed on the Norwalk Agreement (Hail et al., 2010; FASB, 2012, IASB, 2012). Secondly, countries that have introduced mandatory IFRS adoption for publicly listed companies, as well as, countries that voluntarily allow the implementation of IFRS in combination with their domestic standards can be distinguished. Differences in the effects between mandatory and voluntary IFRS adoption vary as well (Christensen et al., 2007; Hail et al., 2010; Landsman et al., 2011; Yu, 
2011).

In 2005, all member states of the EU imposed the mandatory use of IFRS for all their publicly listed companies. Moreover, Australia, South Africa, and Turkey permitted IFRS adoption for publicly listed companies since 2005. Some other major economies that have recently been affected by IFRS adoption are for instance: Argentina, Brazil, Canada, Japan, Korea, Mexico, Russia, and Saudi Arabia (IFRS, 2012). Recent IFRS adoption can also be found in Argentina, Mexico and Russia, since they began with incorporating IFRS from 2012 (PWC, 2012). Canada and Korea joined the rest of the world in IFRS adoption in 2011 and finally Japan first started to incorporate IFRS in 2010 for a number of their international companies (IFRS, 2012).

Other countries that have been affected by the worldwide process towards IFRS adoption are Saudi Arabia, China, India, Indonesia, and last but not least the US. Saudi Arabia is yet undecided about full convergence, although IFRS has already been permitted for all their banking and insurance companies (PWC, 2012). China has been affected by IFRS, as the convergence of IFRS with national standards has substantially started. India is also planning to converge with IFRS and Indonesia is, also, under an ongoing convergence process, but at a date that still needs to be confirmed (IASPlus, 2012). Finally, the US has been in an intensive debate of IFRS adoption, since they started the convergence process between US GAAP and IFRS in 2002 (Cascini \& Rich, 2008; Hail et al., 2010; IASPlus, 2012). It is evident that with currently more than 120 countries in the world and over 12,000 companies implementing IFRS, the reporting standards have developed into a worldwide dominantly uniform reporting language (Hail et al., 2010; AICPA, 2012).

\subsection{Towards IFRS Adoption in the United States: Foreign Issuers}

A lot of research has already been conducted in order to examine the pros and cons of IFRS adoption by inquiring countries that have earlier adopted IFRS for all publicly listed companies (e.g. Ball, 2006; Armstrong et al., 2008; Cascini \& Rich, 2008; Jeanjean \& Stolowy, 2008; Paananen \& Lin, 2008; Sunder \& Watts, 2010; Hail et al., 2010; Fosbre et al., 2011; Sun et al., 2011; Kang et al., 2012). The arguments emanating from prior research are used by the current debate in the US about the pros and cons of IFRS (IASPlus, 2012; SEC, 2012). However, prior research has suggested that the effect of IFRS adoption depends on country specific factors, firm characteristics and other institutional factors, therefore the intensive debate about IFRS in the US is based on evidence that does not compulsory apply in the specific US context (Ali \& Hwang, 2000; Durand \& Tarca, 2005; Papadaki, 2005; Burgstahler et al., 2006; Chua \& Taylor, 2008).

Some important key players of this debate are the FASB, the IASB, the American Institute of Certified Public Accountants (AICPA) and the US SEC (Jermakokowicz \& Tomaszweski, 2006). Since the FASB and the IASB signed the Norwalk agreement, they have been working towards uniform reporting standards (Langmead \& Soroosh, 2010; FASB, 2012; IASB, 2012). The main goal was to eliminate the differences between the standards, with the main goal to eventually adopt a single set of high quality global reporting standards (Hail et al., 2010). In order to further enhance this process, the SEC proposed an official roadmap in 2008 for full IFRS adoption by all publicly listed companies in the US (Langmead \& Soroosh, 2010).

The target date to decide on mandatory IFRS adoption in the US was set in 2011. Then the SEC had planned the time period 2014 to 2016 as the IFRS adoption dates for all publicly listed companies in the US, whereas first to permit large accelerated filers to adopt IFRS and then require mandatory IFRS adoption for accelerated filers, as well as, non-accelerated files (PWC, 2012). The process of mandatory IFRS adoption in the US could only be implemented if the condition to meet seven key milestones would be accomplished (Ostling, 2008; IFRS 2012).

Although the SEC indicated 2011 as the target date for deciding on IFRS adoption in the US for all publicly listed companies, the US failed to do so. It is still unclear precisely when and whether the US will go forward with IFRS adoption for all publicly listed companies.

"United States Securities Exchange Commission Commissioner E. B. Walter has recently given a speech announcing that the "staff expects to publish its final report under the Work Plan in a matter of weeks" (SEC, 2012, May 22), after which the SEC will "consider the next steps" (SEC, 2012, May 22) on the question of the possible adoption of IFRS in the United States". (IASPlus, 2012).

Nonetheless, before the SEC proposed the roadmap in 2008, a year earlier they already released a new reconciliation rule for IFRS adoption to a specific category of companies in the US for the first time. On November 15, 2007, the SEC started to allow the option to all foreign issuers in the US to file IFRS reports without reconciliation to US GAAP, making it almost inevitable for the US to further consider IFRS adoption for other companies (Kaya \& Pillhover, 2013; Kang et al., 2012). The effectiveness date of voluntary IFRS adoption by foreign issuers in the US was on March 4, 2008 (Yu, 2011). 
A foreign issuer can be defined as '(...) any non-US issuer, unless more than 50 percent of the issuer's outstanding voting securities are held by US residents, and either the majority of the executive officers or directors are US residents or more than 50 percent of the issuer's assets are located in the US or its business is administered principally in the US' (Securities Act of 1933, 2012). It refers to large multinational corporations with their foreign subsidiaries, as well as to some US subsidiaries of foreign-owned companies. If a foreign company has the status of a foreign issuer in the US, it will have certain benefits; additionally the foreign issuer is allowed to voluntarily choose to incorporate IFRS without reconciliation to US GAAP in their 20-F filing or otherwise stay with the prior reconciliation requirement (Durand \& Tarca, 2005; Sun et al., 2011; Yu, 2011; Kang et al., 2012).

The range of announcements by the SEC shows that the US certainly already has been affected by IFRS in different ways and would be a motivating factor to start the process towards IFRS adoption for more companies in the US (SEC, 2012). However, the way foreign issuers listed in the US perceive the option to voluntarily adopt IFRS might differ among them (Joos \& Leung, 2013; Kaya \& Pillhover, 2013).

\subsection{Consequences of IFRS Adoption: Foreign Issuers}

As more and more countries in the world have started to adopt IFRS as their main financial reporting language, the debate amongst advocates and opponents has consequently become more intense. Prior research has found evidence that the US has already been affected by the worldwide IFRS adoption in such a way that US firms have become less attractive to foreign investors since IFRS became a more dominant uniform reporting language than US GAAP (Defond et al., 2011). Thus, the attractiveness of a country by international investors is positively related to the use of IFRS as dominant reporting language.

According to the SEC (2012), foreign issuers possess the largest amounts of US treasurers in the world. Therefore, foreign issuers have a strong presence in the US economy (Woo, 2011). In addition, there are many companies that are rivalries of the US in terms of size, growth and technology. In order to make their decision upon whether to choose to reconcile under either IFRS or US GAAP, i.e. voluntary IFRS adoption, it is essential for foreign issuers to outweigh the pros and cons of both standards. Much of the prior research on the effects of IFRS and US GAAP, reveals that there is no consensus (Hail et al., 2010).

The advocates argue that IFRS leads, inter alia, to improving reporting quality and has positive economic consequences (Ball, 2006; Armstrong et al., 2008; Jeanjean \& Stolowy, 2008; Hail et al., 2010). For instance, IFRS is associated to increased market value and market liquidity, as well as, to lower cost of capital, when the companies operate in common law countries with strong legal systems (Daske et al., 2008). Furthermore, they state that IFRS can address the high need for transparency and comparability in terms of financial statement reporting. Moreover, prior research focused on foreign issuers that use IFRS revealed that the reporting standards indeed increases comparability of the companies' financial reporting information, as it is less costly to compare companies' information across different companies' financial statements (Barth et al., 2010). Sun et al. (2011) also found that the use of IFRS by foreign issuers in the US is positively associated to high earnings quality, i.e. increases earnings persistence and small positive earnings. Yu (2011) stated that IFRS adoption by foreign issuers in the US has a positive effect on voluntary disclosures in their financial reporting, while Soderstrom and Sun (2007) claimed that transparency and efficiency increases when foreign issuers use IFRS. According to Latridis and Rouvolis (2010) IFRS improve value relevance of information, while Barth et al. (2008) found that the reporting quality increases for foreign issuers that voluntarily implement IFRS.

On the contrary, Gorden et al. (2010) found that the earnings attributes, which measured earnings quality, are fairly comparable under IFRS and US GAAP in the case of the listed foreign issuers in the US. A small difference is observed that US GAAP does lead to incremental as well as relative value relevance, while IFRS only leads to incremental value relevance. Consistent with Ali and Hwang (2000), Durand and Tarca (2005) also stated that the effect of reporting standards differs amongst foreign issuers and that it depends on country specific factors, such as the countries' legal system, investors' protection and the quality of auditing.

Furthermore, so far, there is insufficient evidence indicating that specific reporting standards would be superior to the other reporting standards (Jamal et al., 2008). Leuz (2003) and Bartov et al. (2005) found that there is no significant difference between IFRS and US GAAP earnings. Additionally, Jeanjean, and Stolowy (2008) found that IFRS adoption did not have an effect on earnings management in some countries and in specific situations earnings management even increased. There is even evidence that US GAAP provides higher quality reporting information compared to IFRS (van der Meulen et al, 2007). Opponents of IFRS adoption for the foreign issuers also argue that by using IFRS in the US, the comparability of financial statement information furthermore decreases. Investors in the US give preference to the reconciliation with US GAAP, since it makes financial 
reporting information more comparable (Hopkins et al., 2008). Therefore, the need of foreign issuers to voluntarily choose to incorporate IFRS decreases (Kang et al., 2012). Moreover it is argued that IFRS adoption causes problems in global accounting harmonization, increasing complexity of financial reporting, transition costs and other implementation problems, such as insufficient knowledge and a lack of political power (Larson \& Street, 2004; Hail et al., 2010).

As the findings from prior research on IFRS and US GAAP vary a lot, the debate of mandatory IFRS adoption in the US for publicly listed companies continues. Since foreign issuers listed in the US are allowed to voluntarily adopt IFRS, it is feasible to investigate the effect of IFRS adoption in the US context. It is important to consider that the decision of foreign issuers to choose to reconcile with IFRS, is also based on a self selection process including firm specific characteristics (Kang et al., 2012). This paper contributes to academic literature with more recent and reliable evidence on the effects of IFRS adoption, due to the time interval applied on a sample of foreign issuers in a specific US context.

\subsection{IFRS and Earnings Quality}

The conceptual framework of accounting defines earnings "(...) as a measure of value created by the firm" (Kirschenheiter \& Melumad, 2004). The Statement of Financial Accounting Concept (SFAC) \#1 says that: "financial reporting is primarily focusing on information about an enterprise's performance provided by measures of earnings and its components". Moreover, SFAC \#1 measures earnings quality based on how it is useful to the decision making process of the readers of financial statements. Earnings are used to fulfill several objectives to the readers of financial statements, such as evaluating management's performance, estimating earnings power, predicting future earnings and assessing risk.

Since prior research on the effects of IFRS on earnings quality leads to contradictory conclusions and given that they depend on country specific and institutional factors, solid conclusions in a different context can not be drawn (van der Meulen et al., 2007).

\section{Research Hypotheses}

According to prior research the level of earnings quality depends on the reporting standard choice (Kirschenheiter \& Melumad, 2004). Thus, earnings quality is positively related to the decision making of financial statement readers. Furthermore, Sun et al. (2001) found a relationship between IFRS and high earnings quality. Barth et al. (2008) found also that IFRS adoption increases earnings quality, through monitoring by investors. Better comparability between firms' financial reporting information decreases the costs for evaluating the quality of financial statements between different firms. Since firms become more comparable, the incorporation of IFRS has, therefore, put pressure on managers to reduce their earnings management. Ewert and Wagenhoffer (2005) also found that tightening accounting standards reduces earnings management and leads to higher reporting quality. Moreover, Lang et al. (2003) stated that foreign issuers which are listed in the US have a lower level of earnings management and accounting quality, than foreign issuers not listed in the US. Christensen et al. (2009) concluded that voluntary IFRS adoption leads to lower earnings management. Following Sun et al. (2011) discretionary accruals is identified as a measurement of earnings management as well as small positive earnings. For foreign issuers in the US that have started to adopt IFRS after the 2007 period onwards, it is then predicted that they will experience lower discretionary accruals, therefore higher accruals quality (Dechow \& Dichev, 2002; Christensen et al., 2009). Therefore, the hypotheses of this paper are:

Hypothesis 1: The post-IFRS adoption period is associated with higher accruals quality, thus higher earnings quality for foreign issuers in the US that have adopted IFRS, because IFRS decrease discretionary accruals.

Hypothesis 2: The post-IFRS adoption period is associated with smaller positive earnings, thus higher earnings quality for foreign issuers in the US that have adopted IFRS, because IFRS decrease earnings management.

\section{Methodology and Data Collection}

\subsection{Methodology}

In order to test the hypothesis, earnings quality, specifically accruals quality, will be compared between the pre-IFRS period and the post-IFRS period. According to prior research the difference-in-differences approach is applied when testing differences between two time periods, as well as, at the same time the differences between two subjects, i.e. in this research pre-IFRS period and post-IFRS period, and foreign issuers that adopt IFRS and otherwise (Beuselinck et al., 2010; Li, 2010; Sun et al., 2011; Kang et al., 2012). Since accruals quality is considered as an earnings attribute for earnings quality, it can be used to examine the change in earnings quality for foreign issuers after the change in accounting standards. The impact on the absolute value of discretionary accruals is examined by the same difference-in-differences ordinary least square (OLS) regression model 
employed by Sun et al. (2011):

$$
\begin{aligned}
A D A C= & b 0+b 1 I F R S+b 2 P O S T+b 3 \text { POST*IFRS }+b 4 S I Z E+b 5 G R O W T H+b 6 E I S S U E+b 7 L E V \\
& +b 8 D I S S U E+b 9 T U R N+b 10 C F O+e
\end{aligned}
$$

Another measure for earnings management is the small positive earnings (Sun et al., 2011), thus the equivalent regression model would be:

$$
\begin{aligned}
S P O S= & b 0+b 1 I F R S+b 2 P O S T+b 3 P O S T * I F R S+b 4 S I Z E+b 5 G R O W T H+b 6 E I S S U E+b 7 L E V+ \\
& b 8 D I S S U E+b 9 T U R N+b 10 C F O+e
\end{aligned}
$$

Where the dependant variable in equation (1) is:

"ADAC = the absolute value of discretionary accruals estimated by the modified Jones (1991) model;

And the dependant variable in equation (2) is:

SPOS $=$ the frequency of small positive earnings that measures earnings management; that is coded 1 if net income scaled by total assets is between 0 and 0.01 and 0 otherwise;

Independent variables are:

IFRS $=$ a dummy variable coded as 1 if foreign issuers use IFRS and 0 if otherwise;

$\mathrm{POST}=$ a dummy variable coded as 1 for foreign issuers in the post-IFRS period using IFRS and 0 if otherwise.

SIZE = firm size, measured as the log of market value of common equity;

GROWTH = growth, measured as the annual percentage change in sales;

EISSUE = increase in equity, measured as the annual percentage change in common equity;

$\mathrm{LEV}=$ leverage, measured as ratio of the total liabilities to common equity;

DISSUE = increase in debt, measured as the annual percentage change in total liabilities;

TURN $=$ turnover, measured as the ratio of sales to total assets;

$\mathrm{CFO}=$ cash flow from operations, measured as the cash flow from operations deflated by total assets", (Sun et al., 2011).

The absolute value of discretionary accruals is calculated using a modified Jones (1991) model, but the change in revenues is modified for a change in receivables in the full sample period (Dechow et al., 1995; van Tendeloo \& Vanstaelen, 2005). Discretionary accruals can be defined as: "the actual total reported accruals minus expected normal accruals" (Dechow et al., 1995).

The model of equation 1 is used because it is able to consider two different time periods, as well as, the differences between the time periods in terms of IFRS adoption. The dependant variable is $A D A C$ and the explanatory variables are IFRS and POST, with a dummy IFRS representing foreign issuers that choose to change report under IFRS. POST represents a dummy variable that is created in order to distinguish the available data into two different time periods, i.e. a pre-IFRS period and post-IFRS period. The post IFRS period implies voluntary IFRS adoption by foreign issuers in the US.

b1 reflects the difference in $A D A C$ between foreign issuers in the US that have changed their accounting standards into IFRS and it also refers to the differences between the different groups of foreign issuers. $b 2$ represents an incremental effect in ADAC for foreign issuers that have not changed their accounting standards into IFRS from the pre-IFRS period to the post-IFRS period and it controls for unrelated changes in ADAC, due to other than changing of accounting standards into IFRS (Sun et al., 2011). The incremental change in ADAC for foreign issuers that are users of IFRS in the post and pre-period and those of foreign issuers that are non-users of IFRS in the post and pre-period is captured by $b 3$. Therefore, if the coefficient of $b 3$ is negative, it can be concluded that IFRS is associated to a decrease in accrual-based earnings management, which entails improved earnings quality (Barth et al., 2008; Jeanjean \& Stolowy, 2008). The coefficients $b 4$ to $b 10$ refer to the impact of the other independent variables of the model on earnings quality.

\subsection{Sample of the Study}

In 2007, the US SEC issued a new reconciliation rule which allowed foreign issuers in the US to voluntarily adopt IFRS. International companies located in the US, such as large multinational corporations and some US subsidiaries of foreign-owned companies chose to report under IFRS (AICPA, 2012). The rule became effective in the beginning of 2008. The sample of this study consists of foreign issuers registered with the US Securities and Exchange Commission. The necessary data are available in Compustat. 
The reason for including these foreign issuers to the sample selection is that they are required by the SEC to file a form 20-F, therefore they have to meet enhancements of reporting and provide better reliable information and disclosure (Amir et al., 1993; SEC, 2012). Moreover, Glaum \& Street (2003) state that in a non-SEC environment, disclosures would result in a lower reporting quality, thus, foreign issuers registered with the SEC would be a better sample for our inquiry.

As for December 31, 2011, a total of 965 foreign companies were registered and reporting with the US SEC. A list of these foreign issuers is published by the SEC and can be collected from the SEC website. The foreign issuers' company names were entered in Compustat in order to obtain the matching company incorporation codes. A number of foreign issuers that were unable to be identified in Compustat were excluded from the full sample selection. The data of the remainder foreign issuers were obtained from the North-America Compustat database and the sample selection consists of foreign issuers in the US categorized from 44 different countries (Appendix).

The different interval time periods are the pre-IFRS and post-IFRS adoption period applying to foreign issuers in the US, i.e. 2002 to 2006 for the pre-IFRS period and 2008 to 2011 for the post-IFRS period. A total of 3049 firm-observations can be obtained for the period 2002 to 2006 and 2008 to 2011, which are the foreign issuers that file a form 20-F with the SEC in 2011. In the pre-IFRS period the total firm-observations are 1311 and in the post-IFRS period 1738. As mentioned above, firms not identified in Compustat were excluded from sample selection. Table 1 presents the sample selection.

Table 1. Foreign issuers in the US included in the sample selection

\begin{tabular}{|c|c|c|c|c|}
\hline \multicolumn{5}{|c|}{ Panel A: Firm-observations of sample selection by period } \\
\hline \multicolumn{2}{|l|}{ Time period } & \multirow{2}{*}{$\begin{array}{c}\text { Frequency } \\
73\end{array}$} & \multicolumn{2}{|r|}{ Percent $(\%)$} \\
\hline \multirow[t]{3}{*}{ Pre-IFRS period } & IFRS & & \multicolumn{2}{|r|}{2.39} \\
\hline & Otherwise & 2.976 & \multicolumn{2}{|r|}{97.61} \\
\hline & Total & 3.049 & \multicolumn{2}{|r|}{100.00} \\
\hline \multirow[t]{3}{*}{ Post -IFRS period } & IFRS & 409 & \multicolumn{2}{|r|}{13.41} \\
\hline & Otherwise & 2.640 & \multicolumn{2}{|r|}{86.59} \\
\hline & Total & 3.049 & \multicolumn{2}{|r|}{100.00} \\
\hline \multicolumn{5}{|c|}{ Panel B: Firm-observations of sample selection by year } \\
\hline Year & IFRS adoption & Non-IFRS adoption & Total & Percent (\%) IFRS \\
\hline \multicolumn{5}{|l|}{ Pre-IFRS period } \\
\hline 2003 & 0 & 294 & 294 & 0.00 \\
\hline 2004 & 6 & 318 & 324 & 1.89 \\
\hline 2005 & 32 & 331 & 363 & 9.67 \\
\hline 2006 & 35 & 295 & 330 & 11.86 \\
\hline \multicolumn{5}{|l|}{ Post-IFRS period } \\
\hline 2008 & 61 & 362 & 423 & 14.42 \\
\hline 2009 & 85 & 389 & 474 & 17.93 \\
\hline 2010 & 106 & 363 & 469 & 23.20 \\
\hline 2011 & 157 & 215 & 372 & 41.82 \\
\hline Total & 482 & 2.567 & 3049 & 15.81 \\
\hline
\end{tabular}

Panel A shows a total of 409 firms-observations used IFRS in the post-IFRS period, while 2640 firms used other accounting standards. However, 73 firms also used IFRS in the pre-IFRS period, due to the mandatory IFRS adoption for all publicly listed companies in countries such as Australia, South Africa and all European Member countries since 2005 (IFRS, 2012; IASPlus, 2012). Panel B presents the frequency of firm-observations for foreign per year from 2003 to 2011. Foreign issuers that are identified as IFRS users in the pre-IFRS period can be classified as mandatory adopters, since they are meeting their home countries' specific reporting requirements in the pre-IFRS period (Hail et al., 2010). The sample selection divided by the country of origin of the foreign issuers, the country's legal system, as well as by the IFRS and non-IFRS adoption, in the pre-period and post-period is presented in the Appendix 


\section{Research Results}

\subsection{Descriptive Statistics}

Table 2 shows the descriptive statistics of the model variables and their statistical differences between IFRS and non-IFRS users and between pre-IFRS and post-IFRS period. Panel A presents the descriptive statistics and the statistical differences of the model variables between IFRS and non-IFRS users. It is found that foreign issuers using IFRS are significantly larger companies than non-IFRS users. Moreover, IFRS users are found to have a higher turnover, higher cash flows from operations and a lower total debt level, although their leverage is higher compared to non-IFRS users. However, IFRS users have a lower growth rate and lower equity than non-IFRS users. Moreover, the non-IFRS users present higher absolute value of discretionary accruals than IFRS users. Therefore, it can be concluded that IFRS adoption does not lead to greater discretionary accruals. Furthermore, small positive earnings are statistically insignificant lower for IFRS users than for non-IFRS users.

Table 2. Descriptive statistics of the model variables and statistical differences between IFRS and non-IFRS users and between pre-IFRS and post-IFRS period

\begin{tabular}{|c|c|c|c|c|c|c|}
\hline \multicolumn{7}{|c|}{ Panel A: Descriptive statistics of discretionary accruals, IFRS users versus non-IFRS users (IFRS) } \\
\hline & \multicolumn{2}{|c|}{ IFRS foreign issuers } & \multicolumn{2}{|c|}{ Non-IFRS foreign issuers } & \multicolumn{2}{|c|}{ Wilcoxon signed rank sum } \\
\hline Variable & Mean & Median & Mean & Median & $t$-statistic & p-value \\
\hline ADAC & 0.0705 & 0.0372 & 0.0846 & 0.0507 & 3.4100 & 0.0006 \\
\hline SPOS & 0.0270 & 0.0000 & 0.0339 & 0.0000 & 0.7830 & 0.4338 \\
\hline POST & 0.8485 & 1.0000 & 0.0000 & 0.0000 & -50.1480 & 0.0000 \\
\hline SIZE & 7.0190 & 7.3480 & 5.3520 & 5.3117 & -12.0040 & 0.0000 \\
\hline GROWTH & 0.2187 & 0.1203 & 0.2461 & 0.1413 & 0.9320 & 0.3514 \\
\hline EISSUE & 0.1990 & 0.0712 & 0.3104 & 0.0978 & 1.5910 & 0.1116 \\
\hline LEV & 0.9175 & 0.8663 & 0.7852 & 0.5491 & -4.1160 & 0.0000 \\
\hline DISSUE & 0.2651 & 0.0897 & 0.4668 & 0.0984 & 1.7680 & 0.0770 \\
\hline TURN & 0.6079 & 0.5651 & 0.5362 & 0.4799 & -4.8680 & 0.0000 \\
\hline $\mathrm{CFO}$ & 0.0601 & 0.1065 & 0.0182 & 0.0701 & -6.8790 & 0.0000 \\
\hline \multicolumn{7}{|c|}{ Panel B: Descriptive statistics of discretionary accruals, 2002 to 2006 and 2008 to 2011 (POST) } \\
\hline & \multicolumn{2}{|c|}{ Pre-IFRS period } & \multicolumn{2}{|c|}{ Post-IFRS period } & \multicolumn{2}{|c|}{ Wilcoxon signed rank sum } \\
\hline Variable & Mean & Median & Mean & Median & t-statistic & p-value \\
\hline ADAC & 0.0844 & 0.0504 & 0.0691 & 0.0377 & 0.7290 & 0.0020 \\
\hline SPOS & 0.0293 & 0.0000 & 0.0333 & 0.0000 & 0.4220 & 0.6731 \\
\hline IFRS & 0.0277 & 0.0000 & 1.0000 & 1.0000 & -14.8020 & 0.0000 \\
\hline SIZE & 5.4789 & 5.3790 & 5.6973 & 5.6165 & -2.1250 & 0.0336 \\
\hline GROWTH & 0.2439 & 0.1410 & 0.3042 & 0.1687 & -6.4760 & 0.0000 \\
\hline EISSUE & 0.2234 & 0.0684 & 0.3470 & 0.1145 & -3.5250 & 0.0004 \\
\hline LEV & 0.9184 & 0.5748 & 0.7089 & 0.6027 & -1.3340 & 0.1821 \\
\hline DISSUE & 0.3751 & 0.0853 & 0.4745 & 0.1022 & -3.7190 & 0.0002 \\
\hline TURN & 0.5486 & 0.4978 & 0.5464 & 0.4965 & -0.8210 & 0.4115 \\
\hline $\mathrm{CFO}$ & 0.0196 & 0.0710 & 0.0585 & 0.1047 & -3.7190 & 0.0002 \\
\hline
\end{tabular}

Panel B shows the differences between the pre-IFRS period and the post-IFRS period for foreign issuers. The size, the growth, the debt level and the equity of the companies are greater in the post-IFRS time period than in the pre-IFRS, The same applies to the turnover, but it is statistically insignificant. The leverage is lower in the post-IFRS period compared to the pre-IFRS period. In the post-IFRS period the absolute value of discretionary accruals is lower compared to the pre-IFRS period, which is consistent with the findings from panel A. Small positive earnings are found to be statistically insignificant higher in the post-IFRS adoption period.

\subsection{Correlation Analysis Results}

Table 3 presents the Pearson correlation analysis of all the variables of the regression model for discretionary accruals. The absolute value of the discretionary accruals is correlated with all the independent variables of the model, except than leverage and turnover. A significant negative, but low, correlation is found between the absolute value of discretionary accruals and foreign issuers that are IFRS users, indicating they have a higher accruals quality (Sun et al., 2011). There is also a significant negative, but low, correlation between IFRS period 
and discretionary accruals, thus absolute value of discretionary accruals is associated with higher accruals quality (Jones, 1991; Dechow, 1995; Dechow \& Dichev, 2002).

Discretionary accruals are highly and significantly negatively correlated with firm size and cash flow from operations, so firms that adopt IFRS are usually larger of size. This could also be due to the fact that foreign issuers listed with the SEC and preparing a F-form are usually larger of size (Durand \& Tarca, 2005). High positive correlations are found with firm growth, equity and debt, indicating that rapidly growing firms, with higher equity and debt usually have lower accruals quality. IFRS use is positively correlated with firm size, turnover and cash flows from operations, while it is negatively correlated with debt level.

Table 3. Pearson correlation matrix for discretionary accruals and independent variables

\begin{tabular}{|c|c|c|c|c|c|c|c|c|c|c|}
\hline Variable & ADAC & IFRS & POST & IFRS*POST & SIZE & GROWTH & EISSUE & LEV & DISSUE & TURN \\
\hline IFRS & $\begin{array}{l}-0.0482 \\
(0.0078)\end{array}$ & & & & & & & & & \\
\hline POST & $\begin{array}{l}-0.0492 \\
(0.0066)\end{array}$ & $\begin{array}{c}0.9083 \\
(0.0000)\end{array}$ & & & & & & & & \\
\hline IFRS*POST & $\begin{array}{l}-0.0492 \\
(0.0066)\end{array}$ & $\begin{array}{c}0.9083 \\
(0.0000)\end{array}$ & $\begin{array}{c}0.3632 \\
(0.0000)\end{array}$ & & & & & & & \\
\hline SIZE & $\begin{array}{l}-0.3272 \\
(0.0000)\end{array}$ & $\begin{array}{c}0.2442 \\
(0.0000)\end{array}$ & $\begin{array}{c}0.0452 \\
(0.0198)\end{array}$ & $\begin{array}{c}0.2051 \\
(0.0000)\end{array}$ & & & & & & \\
\hline GROWTH & $\begin{array}{c}0.1515 \\
(0.0000)\end{array}$ & $\begin{array}{l}-0.0179 \\
(0.4291)\end{array}$ & $\begin{array}{c}0.1142 \\
(0.0000)\end{array}$ & $\begin{array}{l}-0.0116 \\
(0.6067)\end{array}$ & $\begin{array}{l}-0.0593 \\
(0.0141)\end{array}$ & & & & & \\
\hline EISSUE & $\begin{array}{c}0.1076 \\
(0.0000)\end{array}$ & $\begin{array}{l}-0.0207 \\
(0.3445)\end{array}$ & $\begin{array}{c}0.0297 \\
(0.1753)\end{array}$ & $\begin{array}{c}-0.0064 \\
(0.7691)\end{array}$ & $\begin{array}{c}0.0153 \\
(0.5092)\end{array}$ & $\begin{array}{c}0.1154 \\
(0.0000)\end{array}$ & & & & \\
\hline LEV & $\begin{array}{l}-0.0200 \\
(0.2736)\end{array}$ & $\begin{array}{c}0.0088 \\
(0.6294)\end{array}$ & $\begin{array}{l}-0.0192 \\
(0.2925)\end{array}$ & $\begin{array}{l}-0.0019 \\
(0.9170)\end{array}$ & $\begin{array}{l}-0.0360 \\
(0.0637)\end{array}$ & $\begin{array}{c}0.0005 \\
(0.9838)\end{array}$ & $\begin{array}{l}-0.0288 \\
(0.1888)\end{array}$ & & & \\
\hline DISSUE & $\begin{array}{c}0.1526 \\
(0.0000)\end{array}$ & $\begin{array}{l}-0.0497 \\
(0.0225)\end{array}$ & $\begin{array}{c}0.0313 \\
(0.1501)\end{array}$ & $\begin{array}{l}-0.0557 \\
(0.0105)\end{array}$ & $\begin{array}{l}-0.0591 \\
(0.0108)\end{array}$ & $\begin{array}{c}0.3303 \\
(0.0000)\end{array}$ & $\begin{array}{c}0.1188 \\
(0.0000)\end{array}$ & $\begin{array}{l}-0.0191 \\
(0.3832)\end{array}$ & & \\
\hline TURN & $\begin{array}{l}-0.0031 \\
(0.8643)\end{array}$ & $\begin{array}{c}0.0627 \\
(0.0005)\end{array}$ & $\begin{array}{c}0.0026 \\
(0.8848)\end{array}$ & $\begin{array}{c}0.0506 \\
(0.0052)\end{array}$ & $\begin{array}{c}0.0928 \\
(0.0000)\end{array}$ & $\begin{array}{c}0.0104 \\
(0.6451)\end{array}$ & $\begin{array}{c}0.0249 \\
(0.2565)\end{array}$ & $\begin{array}{c}0.0329 \\
(0.0714)\end{array}$ & $\begin{array}{l}-0.1453 \\
(0.0000)\end{array}$ & \\
\hline $\mathrm{CFO}$ & $\begin{array}{l}-0.2421 \\
(0.0000)\end{array}$ & $\begin{array}{c}0.0560 \\
(0.0020)\end{array}$ & $\begin{array}{c}0.0334 \\
(0.0654)\end{array}$ & $\begin{array}{c}0.0484 \\
(0.0075)\end{array}$ & $\begin{array}{c}0.4861 \\
(0.0000)\end{array}$ & $\begin{array}{c}0.0524 \\
(0.0206)\end{array}$ & $\begin{array}{c}0.0286 \\
(0.1915)\end{array}$ & $\begin{array}{c}0.0415 \\
(0.0231)\end{array}$ & $\begin{array}{c}-0.0092 \\
(0.6726)\end{array}$ & $\begin{array}{c}0.2122 \\
(0.0000)\end{array}$ \\
\hline
\end{tabular}

\subsection{Regression Analysis Results}

Table 4 presents the results of the regression model for the discretionary accruals model. According to panel A. foreign issuers that are non-IFRS adopters exhibit higher discretionary accruals, meaning that their accruals quality is lower when using standards other than IFRS. The coefficient of the POST variable is insignificant, implying that there no significant change from the pre-IFRS to post-IFRS period, in terms of discretionary accruals absolute value.

Table 4. Multivariate regression analysis for absolute discretionary accruals

\begin{tabular}{|c|c|c|c|c|c|}
\hline \multicolumn{6}{|c|}{ Panel A: Difference-in-differences regression (Number of observations=1705) } \\
\hline \multicolumn{6}{|c|}{$\begin{array}{l}A D A C=b 0+b 1 I F R S+b 2 P O S T+b 3 P O S T * I F R S+b 4 S I Z E+b 5 G R O W T H+b 6 E I S S U E+b 7 L E V+b 8 D I S S U E+ \\
b 9 T U R N+b 10 C F O+e\end{array}$} \\
\hline Variable & & Coefficient & Std. Error & T-statistic & P-value \\
\hline Intercept & b0 & 0.1155954 & 0.0077066 & 15.00 & 0.000 \\
\hline IFRS & b1 & 0.0275352 & 0.0115988 & 2.37 & 0.018 \\
\hline POST & $\mathrm{b} 2$ & 0.0045912 & 0.004543 & 1.01 & 0.312 \\
\hline POST*IFRS & b3 & -0.0168027 & 0.0129877 & -1.29 & 0.196 \\
\hline SIZE & $\mathrm{b} 4$ & -0.0100459 & 0.001062 & -9.46 & 0.000 \\
\hline GROWTH & b5 & 0.019634 & 0.0036701 & 5.35 & 0.000 \\
\hline EISSUE & b6 & 0.0044945 & 0.0011247 & 4.00 & 0.000 \\
\hline LEV & b7 & -0.000974 & 0.0005185 & -1.88 & 0.060 \\
\hline DISSUE & b8 & 0.0083825 & 0.0017927 & 4.68 & 0.000 \\
\hline
\end{tabular}




\begin{tabular}{|c|c|c|c|c|c|}
\hline TURN & b9 & 0.0163874 & 0.0055922 & 2.93 & 0.003 \\
\hline $\mathrm{CFO}$ & b10 & -0.0673975 & 0.0141959 & -4.75 & 0.000 \\
\hline $\mathrm{N}$ & 1705.00 & & & & \\
\hline $\mathrm{F}$ & 31.90 & & & & \\
\hline Prob $>\mathrm{F}$ & 0.0000 & & & & \\
\hline Adj. $R^{2}$ & $15.35 \%$ & & & & \\
\hline \multicolumn{6}{|c|}{ Panel B: Separate group coefficients (Number of observations=1705) } \\
\hline Variable & & Coefficient & Std. Error & T-statistic & P-value \\
\hline Foreign issuers and IFRS, Pre-IFRS period & b0 & 0.0890933 & 0.0030203 & 29.50 & 0.950 \\
\hline Foreign issuers and IFRS, Post-IFRS period & b2 & -0.0086854 & 0.0041976 & -2.07 & 0.039 \\
\hline Foreign issuers non-IFRS, Pre-IFRS period & b1 & -0.0104356 & 0.0127995 & -0.82 & 0.415 \\
\hline Foreign issuers non-IFRS, Post-IFRS period & $\mathrm{b} 1+\mathrm{b} 2+\mathrm{b} 3$ & -0.0008863 & 0.0141399 & -0.06 & 0.000 \\
\hline \multicolumn{6}{|c|}{ Panel C: Coefficient differences between groups (Number of observations=1705) } \\
\hline & & & Difference & T-statistic & F-statistic \\
\hline \multicolumn{3}{|c|}{ IFRS Foreign issuers: Pre-IFRS period vs Post-IFRS period } & 0.0416694 & 2.6477 & 1.6272 \\
\hline \multicolumn{3}{|l|}{ Post-IFRS period: IFRS firms vs non-IFRS firms } & 0.4274733 & 37.1280 & 6.09328 \\
\hline
\end{tabular}

The coefficient of IFRS*POST represents the difference-in-differences; therefore it accounts for the differences between IFRS foreign issuers from a pre-IFRS adoption period into post-IFRS adoption period and of non-IFRS issuers from pre-IFRS adoption period into post-IFRS adoption period. The coefficient of IFRS*POST accounts for the foreign issuers that use IFRS. The coefficient value indicates that there is a negative association between the post-IFRS period and discretionary accruals; however, the coefficient is not statistically significant. According to the results of the regression model, the discretionary accruals value does not statistically change for both IFRS and non-IFRS foreign issuers from the pre-IFRS period to the post-IFRS period. Therefore, in terms of the absolute value of discretionary accruals, voluntary IFRS adoption by the US foreign issuers in the post-IFRS period does not have an effect on accruals quality. Consequently, Hypothesis 1 is rejected, as IFRS adoption by foreign issuers in the US does not increase accruals quality in the period after voluntary IFRS adoption was allowed in the US.

Panel B exhibits the separate subgroup coefficients. Again, a fairly small decrease in discretionary accruals can be observed for IFRS users in the post-IFRS period, but the evidence is not sufficient. Panel C compares the differences between two groups of IFRS foreign issuers and non-IFRS foreign issuers.

Table 5 presents the results of the multivariate regression analysis for small positive earnings. It is found that overall foreign firms that adopt IFRS have smaller positive earnings, but statistically insignificant. The smaller the positive earnings means the less earnings management, consequently higher earnings quality (Sun et al., 2011). So, IFRS users experience smaller positive earnings, implying less earnings management; therefore higher earnings quality in the post-IFRS adoption period. Examining, specifically, the IFRS adoption in the post-IFRS period, foreign issuers also have smaller positive earnings, but again this is insignificant. Furthermore, firms that are larger of size and more leveraged have higher small positive earnings, thus indicating lower earnings quality. When foreign firms are growing more rapidly, the turnover is higher and they are better able to generate cash flows from operations, earnings quality will be higher by showing that they have less small positive earnings. Findings are consistent with hypothesis 2 , thus the second hypothesis will not be rejected.

Table 5. Multivariate regression analysis for small positive earnings

\begin{tabular}{|c|c|c|c|c|c|}
\hline \multicolumn{6}{|c|}{ Panel A: Difference-in-differences regression (Number of observations=1705) } \\
\hline \multicolumn{6}{|c|}{$\begin{array}{l}S P O S=b 0+b 1 I F R S+b 2 P O S T+b 3 P O S T^{*} I F R S+b 4 S I Z E+b 5 G R O W T H+b 6 E I S S U E+b 7 L E V+b 8 D I S S U E+ \\
b 9 T U R N+b 10 C F O+e\end{array}$} \\
\hline Variable & & Coefficient & Std. Error & T-statistic & P-value \\
\hline Intercept & b0 & 0.1155954 & 0.0077066 & 15.00 & 0.000 \\
\hline IFRS & b1 & 0.0275352 & 0.0115988 & 2.37 & 0.018 \\
\hline POST & $\mathrm{b} 2$ & 0.0045912 & 0.004543 & 1.01 & 0.312 \\
\hline POST*IFRS & b3 & -0.0168027 & 0.0129877 & -1.29 & 0.196 \\
\hline SIZE & $\mathrm{b} 4$ & -0.0100459 & 0.001062 & -9.46 & 0.000 \\
\hline GROWTH & b5 & 0.019634 & 0.0036701 & 5.35 & 0.000 \\
\hline EISSUE & b6 & 0.0044945 & 0.0011247 & 4.00 & 0.000 \\
\hline
\end{tabular}




\begin{tabular}{|c|c|c|c|c|c|}
\hline LEV & b7 & -0.000974 & 0.0005185 & -1.88 & 0.060 \\
\hline DISSUE & $\mathrm{b} 8$ & 0.0083825 & 0.0017927 & 4.68 & 0.000 \\
\hline TURN & b9 & 0.0163874 & 0.0055922 & 2.93 & 0.003 \\
\hline $\mathrm{CFO}$ & b10 & -0.0673975 & 0.0141959 & -4.75 & 0.000 \\
\hline \multicolumn{6}{|c|}{ Panel B: Separate group coefficients (Number of observations=1705) } \\
\hline Variable & & Coefficient & Std. Error & T-statistic & P-value \\
\hline Foreign issuers and IFRS, Pre-IFRS period & b0 & 0.0890933 & 0.0030203 & 29.50 & 0.950 \\
\hline Foreign issuers and IFRS, Post-IFRS period & b2 & -0.0086854 & 0.0041976 & -2.07 & 0.039 \\
\hline Foreign issuers non-IFRS, Pre-IFRS period & b1 & -0.0104356 & 0.0127995 & -0.82 & 0.415 \\
\hline Foreign issuers non-IFRS, Post-IFRS period & $\mathrm{b} 1+\mathrm{b} 2+\mathrm{b} 3$ & -0.0008863 & 0.0141399 & -0.06 & 0.000 \\
\hline \multicolumn{6}{|c|}{ Panel C: Coefficient differences between groups (Number of observations=1705) } \\
\hline & & & Difference & T-statistic & F-statistic \\
\hline \multicolumn{3}{|c|}{ IFRS Foreign issuers: Pre-IFRS period vs Post-IFRS period } & 0.0416694 & 2.6477 & 1.6272 \\
\hline \multicolumn{3}{|c|}{ Post-IFRS period: IFRS firms vs non-IFRS firms } & 0.4274733 & 37.1280 & 6.09328 \\
\hline
\end{tabular}

Panel B shows the separate subgroup coefficients for IFRS foreign issuers in the post IFRS-period, non-IFRS foreign issuers in the pre-IFRS period and non-IFRS foreign issuers in the post-IFRS period. Panel C shows the differences between two groups of IFRS foreign issuers and non-IFRS foreign issuers. This also shows that small positive earnings are lower after IFRS, but it is insignificant for the full selection sample.

\subsection{Robustness Test: Discretionary Accruals}

A robustness test for the model of the absolute value of discretionary accruals was also executed (Table 6), in order to examine the effects of the variation in different variables of the model (Van der Heyden et al., 1999). The results from the robustness test are in accordance with the difference-in-differences regression model performed earlier. Since the signs of the coefficients in table 6 are the same as in table 3, it can be concluded that the results are robust.

Table 6. Robustness test for absolute discretionary accruals

\begin{tabular}{|c|c|c|c|c|c|}
\hline \multicolumn{6}{|c|}{$\begin{array}{l}A D A C=b 0+b 1 I F R S+b 2 P O S T+b 3 P O S T * I F R S+b 4 S I Z E+b 5 G R O W T H+ \\
b 6 E I S S U E+b 7 L E V+b 8 D I S S U E+b 9 T U R N b 10 C F O+e\end{array}$} \\
\hline Variable & & Coefficient & Std. Error & T-statistic & $\mathrm{P}$-value \\
\hline Intercept & b0 & 0,1156 & 0,0107 & 10,780 & 0,000 \\
\hline IFRS & b1 & 0,0321 & 0,0133 & 2,410 & 0,016 \\
\hline POST & b2 & 0,0046 & 0,0472 & 0,970 & 0,331 \\
\hline POST*IFRS & b3 & $-0,0260$ & 0,0136 & $-1,920$ & 0,055 \\
\hline SIZE & b4 & $-0,0100$ & 0,0015 & $-6,900$ & 0,000 \\
\hline GROWTH & b5 & 0,0196 & 0,0070 & 2,790 & 0,005 \\
\hline EISSUE & b6 & 0,0045 & 0,0018 & 2,550 & 0,011 \\
\hline LEV & b7 & $-0,0010$ & 0,0008 & $-1,220$ & 0,223 \\
\hline DISSUE & b8 & 0,0084 & 0,0058 & 1,440 & 0,151 \\
\hline TURN & b9 & 0,0164 & 0,0073 & 2,240 & 0,026 \\
\hline $\mathrm{CFO}$ & b10 & $-0,0674$ & 0,0265 & $-2,540$ & 0,011 \\
\hline $\mathrm{N}$ & 1705.00 & & & & \\
\hline F & 13.25 & & & & \\
\hline Prob $>F$ & 0.0000 & & & & \\
\hline Adj. $R^{2}$ & $15.85 \%$ & & & & \\
\hline
\end{tabular}

\section{Conclusion, Limitations, and Recommendations}

Since 2007 foreign issuers in the US were given the option to voluntarily adopt IFRS. This paper examines the effect of IFRS adoption on earnings quality for foreign issuers in the US. More precisely discretionary accruals and small positive earnings are tested for a sample selection of foreign issuers that are registered and reporting with the US SEC. A comparison is made between the pre-period 2002 to 2006 and the post-period 2008 to 2011. The results from the difference-in-differences regression, Pearson correlation and robustness analyses suggest that for discretionary accruals there is no statistically significant difference between the pre-IFRS and the 
post-IFRS period. Therefore, it can be concluded that earnings quality remains unchanged. However, it is found that when foreign issuers incorporate IFRS, small positive earnings are lower, which means that there is less earnings management, implying higher earnings quality.

Results are consistent with prior research on earnings quality and IFRS adoption which indicate that there is no significant difference between IFRS and US GAAP earnings and that IFRS adoption did not affect earnings quality (Leuz, 2003; Bartov et al., 2005; Jeanjean \& Stolowy, 2008; Sun et al., 2011). The findings of small positive earnings are consistent with prior research on different IFRS adopting countries that found that IFRS reduces earnings management and earnings quality (Ewert \& Wagenhoffer, 2005; Lang et al., 2003; Christensen et al., 2009; Sun et al., 2011). Since several findings in this research are insignificant, further tests should be conducted on earnings quality by measuring other earnings attributes for the sample selection of foreign issuers in the US. This is necessary in order to obtain stronger evidence on the effects of IFRS adoption in US specific context.

However, there are some limitations in this study, First of all, our sample includes 20 firm-observations from the financial industry, while most of the prior studies exclude such firms (with a four-digit Standard Industrial Classification (SIC) between 6000 and 6999) because it is difficult to calculate the discretionary accruals for this category of firms (van Tendeloo \& Vanstraelen, 2005; van der Poel \& Vanstraelen, 2011; Boubakri, 2012). However, only 20 of our 3049 firm-observations are from the financial industry. Therefore, it is likely that results would be unaffected by excluding the financial industry.

Another limitation of the research is that countries were manually collected from the SEC website and searched for the ticker company codes in Compustat, but for a certain number of companies the ticker company code could not be identified. The list of foreign issuers contained a total of 965 companies and the foreign issuers that remained unidentified in Compustat were excluded from the sample, whereas 3049 firm-observations remained.

Although, the home countries of the sample foreign issuers have either common or civil law legal system, this research does not consider in its analysis the different country-specific characteristics, such as political, legal, cultural and institutional, which implies a limitation (Ali \& Hwang, 2000; Jermakowicz \& Gornik-Tomaszewski, 2006; Sun et al., 2011). However, the foreign issuers of our sample were all located in the US.

Further tests should be done on earnings quality, because it does not depend only on IFRS. For instance, this research only examined attributes from a category of accounting-based earnings attributes, but stronger evidence could be obtained by combining the analysis with market-based earnings attributes, such as timely loss recognition, conservatism and relevance (van der Meulen et al., 2007; Barth et al., 2008; Jeanjean \& Stolowy, 2008).

\section{References}

AICPA. (2012). AICPA IFRS Resources. Retrieved from http://www.ifrs.com/ifrs_faqs.html\#q3

Ali, A., \& L. H. (2000). Country-specific factors related to financial reporting and the value relevance of accounting data. Journal of Accounting Research, 38(1), 1-21. http://dx.doi.org/10.2307/2672920

Amir, E., Harris, T. S., \& Venuti, E. K. (1993). A Comparison of Value-Relevance of U.S. Versus Non-U.S. GAAP Accounting Measures Using Form 20-F Reconciliations. Journal of Accounting Research, 31, 230-264. http://dx.doi.org/10.2307/2491172

Armstrong, C. S., Barth, M. E., Jagolinzer, A. D., \& Riedl, E. J. (2008). Market Reaction to the Adoption of IFRS in Europe. Working Paper, University of Pennsylvania, Stanford Business School and Harvard Business School. Retrieved from http://www.hbs.edu/faculty/Publication\%20Files/09-032.pdf

Ball, R. (2006). International Financial Reporting Standards (IFRS): Pros and Cons For Investors. Accounting and Business Research, 46(3), 5-27. http://dx.doi.org/10.1080/00014788.2006.9730040

Barth, M. E., Landsman, W. R., Lang, M., \& Williams, C. (2010). Are International Accounting Standards-Based and US GAAP- Based Accounting Amounts Comparable? Working paper, Stanford University. http://dx.doi.org/10.2139/ssrn.1585404

Barth, M. E., Landsman, W. R., \& Lang, M. H. (2008). International Accounting Standards and Accounting Quality. Journal of Accounting Research, 46(3), 467-498. http://dx.doi.org/10.1111/j.1475-679X.2008.00287.x

Bartov, E., Goldberg, S., \& Kim, M. (2005). Comparative Value Relevance Among German, U.S. and International Accounting Standards: A German Stock Market Perspective. Journal of Accounting, Auditing \& Finance, 20(2), 95-119. 
Beuselinck, C., Joos, P., Khurana, I. K., \& van der Meulen, S. (2010). Mandatory IFRS Reporting and Stock Price Informativeness. Working Paper, Catholic University of Lille, Tilburg University and University of Missouri at Columbia. http://dx.doi.org/10.2139/ssrn.1381242

Boubakri, F. (2012). The Relationship between Accruals Quality, Earnings Persistence and Accruals Anomaly in the Canadian Context. International Journal of Economics and Finance, 4(6), 51-62. http://dx.doi.org/10.5539/ijef.v4n6p51

Burgstahler, D., L. Hail, \& Leuz, C. (2006). The importance of reporting incentives: Earnings management in european private and public firms. The Accounting Review, 81(5), 983-1016. http://dx.doi.org/10.2308/accr.2006.81.5.983

Cascini, K., \& Rich, A. (2008). The EU Has Accepted IAS for Listed Companies: Will the U.S. Follow? International Business and Economics Research Journal, 7(4), 11-21.

Christensen, H., Lee, E., \& Walker, M. (2009). Do IFRS Reconciliations Convey Information? The effect of debt $\begin{array}{lllll}\text { contracting. Journal of Accounting Research, 47(5), 1167-1199. } & \text {. }\end{array}$ http://dx.doi.org/10.1111/j.1475-679X.2009.00345.x

Christensen, H. B., Lee, E., \& Walker, M. (2007). Cross-Sectional Variation in the Economic Consequences of International Accounting Harmonization: The case of Mandatory IFRS Adoption in the UK. The International Journal of Accounting, 42(4), 341-379. http://dx.doi.org/10.1016/j.intacc.2007.09.007

Chua, W. F., \& Taylor, S. L. (2008). The Rise and Rise of IFRS: An Examination of IFRS Diffusion. Journal of Accounting and Public Policy, 27, 462-473. http://dx.doi.org/10.1016/j.jaccpubpol.2008.09.004

Chytis, E. (2015). Deferred Tax Assets from unused Tax Losses under the prism of Financial Crisis. Paper presented at the International Conference on Business \& Economics of the Hellenic Open University, Athens. Retrieved from http://193.108.160.55/ocs/index.php/ICBE-HOU_2015/ICBE.

Chytis, E., Koumanakos, E., \& Siriopoulos, C. (2013). Deferred Tax Positions under the prism of financial crisis and the effects of a corporate tax reform. Paper presented at the 12th Annual Conference of the Hellenic Finance and Accounting Association (H.F.A.A.), University of Macedonia, Thessaloniki. Retrieved from http://www.hfaa.gr

Daske, H., Hail, L., Leuz, C., \& Verdi, R. (2008). Mandatory IFRS Reporting Around the World: Early Evidence on the Economic Consequences. Journal of Accounting Research, 46(5), 1085-1142. http://dx.doi.org/10.1111/j.1475-679X.2008.00306.x

Dechow, P., \& Dichev, I. (2002). The Quality of Accruals and Earnings: the Role of Accrual Estimation Errors. The Accounting Review, 77, 35-59. http://dx.doi.org/10.2308/accr.2002.77.s-1.35

Dechow, P. M., Sloan, R. G., \& Sweeney, A. P. (1995). Detecting Earnings Management. The Accounting Review, 70(2), 193-225.

Defond, M., Hu, X., Hung, M., \& Li, S. (2011). The Impact of Mandatory IFRS Adoption on Foreign Mutual Ownership: The Role of Comparability. Journal of Accounting and Economics, 51, 240-258. http://dx.doi.org/10.1016/j.jacceco.2011.02.001

Durand, R. B. \& Tarca, A. (2005). The Impact of US GAAP Reconciliation Requirements on Choice of Foreign Stock Exchange for Firms from Common Law and Code Law Countries. European Accounting Review, 14(4), 789-813. http://dx.doi.org/10.1080/09638180500108536

Ewert, R., \& Wagenhofer, A. (2005). Economic Effects of Tightening Accounting Standards to Restrict Earnings Management. The Accounting Review, 80(4), 1101-1124. http://dx.doi.org/10.2308/accr.2005.80.4.1101

FASB. (2012). Retrieved from www.fasb.org

Fosbre, A. B., Kraft, E. M., \& Fosbre, P. B. (2011). US Adoption of IFRS May Help to Jumpstart the US Economy. Accounting and Taxation, 3(2), 109-117.

Glaum, M., \& Street, D. (2003). Compliance With the Disclosure Requirements of Germany's New Market: IAS versus U.S. GAAP. Journal of International Financial Management \& Accounting, 14(1), 64-100. http://dx.doi.org/10.1111/1467-646X.00090

Gordon, E. A., Jorgensen, B. N., \& Linthicum, C. L. (2010). Could IFRS replace US GAAP? A comparison of earnings attributes and informativeness in the US market. Working Paper. Retrieved from http://business.utsa.edu/wps/acc/0028ACC-006-2010.pdf 
Hail, L., Leuz, C., \& Wysocki, P. (2010). Global Accounting Convergence and the Potential Adoption of IFRS by the United States: Conceptual Underpinnings and Economic analysis. Accounting Horizons, 24(3), 355-394. http://dx.doi.org/10.2308/acch.2010.24.3.355

Hopkins, P. C., Botosan, M., Bradshaw, M., Callahan, C., Ciesielski, J., Farber, D., Hodder, L., Kohlbeck, M., Laux, R., Stober, T., Stocken, P., \& Yohn, T. (2008). Response to the SEC release "acceptance from foreign private issuers of financial statements prepared in accordance with IFRS and without reconciliation to US GAAP File No. S7-13-07." Accounting Horizons, 22(2), 223-240. http://dx.doi.org/10.2308/acch.2008.22.2.223

IASB. (2012). Retrieved from http://www.iasb.org

IASPlus. (2012). Retrieved from http://www.iasplus.com

IASPlus. (2012). US SEC Reports on IFRS Due within weeks. Retrieved from http://www.iasplus.com/en/news/2012/may/us-sec-report-on-ifrs-due-within-weeks

IFRS. (2012a). Retrieved from http://www.ifrs.com

IFRS. (2012b). IFRS Foundation: The Move towards Global Standards. Retrieved from http://www.ifrs.org/Use+around+the+world/Use+around+the+world.htm

Jamal, K., Bloomfield, R., Christensen, T., Colson, R., Moehrle, S., Rajgopal, S., Stober, T., Sander, S., \& Watts, R. L. (2008). A perspective on the SEC's proposal to Accept Financial Statements Prepared in Accordance With International Financial Reporting Standards (IFRS) Without Reconciliation to U.S. GAAP. Accounting Horizons, 22(2), 241-248. http://dx.doi.org/10.2308/acch.2008.22.2.241

Jeanjean, T., \& Stolowy, H. (2008). Do accounting standards matter? An exploratory analysis of earnings management before and after ifrs adoption. Journal of Accounting and Public Policy, 27(6), 480-494. http://dx.doi.org/10.1016/j.jaccpubpol.2008.09.008

Jermakowicz \& Gornik-Tomaszewski. (2006). Implementing IFRS from the Perspective of EU Publicly Traded Companies. Journal of Accounting, Auditing and Taxation, 15(2), 170-196. http://dx.doi.org/10.1016/j.intaccaudtax.2006.08.003

Jones, J. J (1991). Earnings Management During Import Relief Investigations. Journal of Accounting Research, 29(2), 193-228. http://dx.doi.org/10.2307/2491047

Joos, P., \& Leung, E. (2013). Investor Perceptions of Potential IFRS Adoption in the United States. The Accounting Review, 88(2), 577-609. http://dx.doi.org/10.2308/accr-50338

Kang, T., Krishnan, G., Wolfe, M., \& Yi, H. (2012). The Impact of Eliminating the 20-F Reconciliation Requirement for IFRS Filers on Earnings Predictability and Information Uncertainty. Accounting Horizons, 26(4), 741-765. http://dx.doi.org/10.2308/acch-50250

Kaya, D., \& Phillhover, J. A. (2013). Potential Adoption of IFRS by the United States: A Critical View. Accounting Horizons, 27(2), 271-299. http://dx.doi.org/10.2308/acch-50423

Kirschenheiter, M., \& Melumad, N. (2004). Earnings Quality and Smoothing. Working paper, Purdue University and Colombia University. Retrieved from http://www.krannert.purdue.edu/events/bkd_speakers/papers/mikespaper.pdf

Landsman, W. R., Maydew, E. L., \& Thornock, J. R. (2011). The Information Content of Annual Earnings Announcements and Mandatory Adoption of IFRS. Journal of Accounting and Economics, 53(1-2), 34-54. http://dx.doi.org/10.1016/j.jacceco.2011.04.002

Lang, M., Ready, J. S. \& Yetman, M. H. (2003). How Representative Are Firms That Are Cross-listed in theUnited States? An Analysis of Accounting Quality. Journal of Accounting Research, 41(2), 363-386. http://dx.doi.org/10.1111/1475-679X.00108

Langmead, J. M., \& Soroosh, J. (2010). Mapping the Road to IFRS: A Survey of CPAs in Public Practice. CPA Journal, 30-35.

Larson, R. K., \& Street, D. L. (2004). Convergence with IFRS in an Expanding Europe: Progress and Obstacles Identified by Large Accounting Firms' Survey. Journal of International Accounting, Auditing and Taxation, 13, 89-119. http://dx.doi.org/10.1016/j.intaccaudtax.2004.09.002

Latridis, G., \& Rouvolis, S., (2010). The Post-Adoption Effects of the Implementation of International Financial Reporting Standards in Greece. Journal of International Accounting, Auditing and Taxation, 19, 55-65. 
http://dx.doi.org/10.1016/j.intaccaudtax.2009.12.004

Leuz, \& Christian. (2003). Discussion of ADRs, analysts, and accuracy: Does Cross-Listing in the United States Improve a Firm's Information Environment and Increase Market Value? Journal of Accounting Research, 41, 347-362. http://dx.doi.org/10.1111/1475-679X.00107

Li, S. (2010). Does Mandatory Adoption of International Financial Reporting Standards in the European Union Reduce the Cost of Equity Capital? Accounting Review, 85(2), 607-636. http://dx.doi.org/10.2308/accr.2010.85.2.607

Ostling, D. (2008). IFRS: The financial road ahead. The Corporate Board, 173(29), 5-10.

Paananen, M., \& Lin, C. (2009). The Development of Accounting Quality of IAS and IFRS over Time: The Case of Germany. Journal of International Accounting Research, 8(1), 31-55. http://dx.doi.org/10.2308/jiar.2009.8.1.31

Pacter. (2005). What Exactly is Convergence? International Journal of Accounting, Auditing and Performance Evaluation, 2, 67-83. http://dx.doi.org/10.1504/IJAAPE.2005.006893

Papadaki, A. (2005). Discussion of "Why do national GAAP differ from IAS? The role of culture". The International Journal of Accounting, 40, 351-358. http://dx.doi.org/10.1016/j.intacc.2005.09.002

PWC. (2012). IFRS and US GAAP-Similarities and Differences. 1-240. Retrieved from http://www.pwc.com/us/en/issues/ifrs-reporting/assets/ifrs- simdif_book-final-2010.pdf

SEC. (2012). Retrieved from http://www.sec.gov/spotlight/ifrsroadmap.htm. SEC (2012, May 22). Speech by SEC commissioner Elisse B. Walter.

Soderstrom, N. S., \& Sun, K. J. (2007). IFRS Adoption and Accounting Quality. European Accounting Review, 16(4), 675-702. http://dx.doi.org/10.1080/09638180701706732

Sridharan, S., \& Soonawalla, K. (2011). Cost-of-Capital Effects of IFRS Reporting in the United States. http://dx.doi.org/10.2139/ssrn.2000113

Sun, J., Cahan, S. F., \& Emanuel, D. (2011). How Would the Mandatory Adoption of IFRS Affect the Earnings Quality of U.S. Firms? Evidence from Cross-Listed Firms in the U.S. Accounting Horizons: December 2011, Vol. 25, No. 4, pp. 837-860. http://dx.doi.org/10.2308/acch-50049

Sunder, S., \& Watts, R. (2010). A Research-Based Perspective on the SEC's Proposal to Accept Financial Statements Prepared in Accordance With International Financial Reporting Standards (IFRS) by U. S. Issuers. Accounting Horizons, 24(1), 139-147. http://dx.doi.org/10.2308/acch.2010.24.1.139

US SEC. (2012). International Registered and Reporting Companies. Retrieved from http://www.sec.gov/divisions/corpfin/internatl/companies.shtml

Van der Poel, K., \& Vanstraelen, A. (2011). Management reporting on Internal Control and Accruals Quality: Insights from a "Comply or Explain" Internal Control Regime. Auditing, Journal of Practice and Theory, 30(3), 181-209. http://dx.doi.org/10.2308/ajpt-10052

Van der Heyden, Y., Jimidar, M., Hunda, E., Niemeijers, N., Peeters, R., Smeyers-Verbeke, J., Massart, D. L., \& Hoogmartens, J. (1999). Determination of System Suitability Limits With a Robustness Test. Journal of Chromatography, 845(1-2), 145-154. http://dx.doi.org/10.1016/S0021-9673(99)00328-3

Van der Meulen, S., Gaeremynck, A., \& Willekens, M. (2007). Attribute Differences Between U. S. GAAP and IFRS Earnings: An Exploratory Study. The International Journal of Accounting, 42(2), 123-142. http://dx.doi.org/10.1016/j.intacc.2007.04.001

Van Tendeloo, B., \& Vanstraelen, A. (2005). Earnings Management Under German GAAP Versus IFRS. European Accounting Review, 14(1), 155-180. http://dx.doi.org/10.1080/0963818042000338988

Woo, C. H. N. (2011). United States Securities Regulation and Foreign Private Issuers: Lessons from the Sarbanes-Oxley Act. American Business Law Journal, 48(1), 119-176. http://dx.doi.org/10.1111/j.1744-1714.2010.01113.x

Yu, J. (2011). The Interaction of Voluntary and Mandatory Disclosures: Evidence from the SEC's Elimination of IFRS-U.S.GAAP Reconciliation. Working paper, University of Georgia. http://www3.nd.edu/ carecob/Workshops/10-11\%20Recruiting/Julia\%20Yu\%20Road\%20Paper_Feb\%201. pdf 


\section{Appendix}

Sample selection by country, IFRS, and non-IFRS adoption, in pre-period, post-period, and legal system

\begin{tabular}{|c|c|c|c|c|c|c|c|c|}
\hline \multirow{2}{*}{ Country } & \multirow{2}{*}{$\begin{array}{c}\text { Legal } \\
\text { system }\end{array}$} & \multicolumn{2}{|c|}{ Pre-period } & \multicolumn{2}{|c|}{ Post-period } & \multirow{2}{*}{ (\%) Post-period } & \multirow{2}{*}{ Frequency } & \multirow{2}{*}{ Percent $(\%$} \\
\hline & & IFRS & Non-IFRS & IFRS & Non-IFRS & & & \\
\hline Argentina & CIV & 0 & 50 & 0 & 50 & 0 & 50 & 1.64 \\
\hline Antigua & $\mathrm{COM}$ & 0 & 8 & 0 & 8 & 0 & 8 & 0.26 \\
\hline Australia & $\mathrm{COM}$ & 6 & 50 & 29 & 27 & 51.79 & 56 & 1.84 \\
\hline Belgium & CIV & 0 & 4 & 4 & 0 & 100 & 4 & 0.13 \\
\hline Bahamas & $\mathrm{COM}$ & 0 & 6 & 0 & 6 & 0 & 6 & 0.20 \\
\hline Bermuda & $\mathrm{COM}$ & 0 & 97 & 7 & 90 & 7.22 & 97 & 3.18 \\
\hline Brazil & $\mathrm{CIV}$ & 0 & 122 & 35 & 87 & 28.67 & 122 & 4.00 \\
\hline British Virgin Islands & $\mathrm{COM}$ & 0 & 98 & 6 & 92 & 5.88 & 98 & 3.21 \\
\hline Canada & $\mathrm{COM}$ & 0 & 1005 & 67 & 938 & 6.67 & 1005 & 32.96 \\
\hline Switzerland & CIV & 6 & 20 & 9 & 17 & 34.62 & 26 & 0.85 \\
\hline Chile & CIV & 0 & 41 & 8 & 33 & 19.51 & 41 & 1.34 \\
\hline China & $\mathrm{CIV}$ & 9 & 55 & 27 & 37 & 42.19 & 64 & 2.10 \\
\hline Colombia & CIV & 0 & 4 & 0 & 4 & 0 & 4 & 0.13 \\
\hline Cayman Islands & $\mathrm{COM}$ & 0 & 303 & 12 & 291 & 3.96 & 303 & 9.94 \\
\hline Germany & CIV & 2 & 8 & 4 & 6 & 40 & 10 & 0.33 \\
\hline Denmark & CIV & 5 & 11 & 8 & 8 & 50 & 16 & 0.52 \\
\hline Spain & CIV & 2 & 6 & 6 & 2 & 75 & 8 & 0.26 \\
\hline Finland & CIV & 3 & 5 & 4 & 4 & 75 & 8 & 0.26 \\
\hline France & CIV & 8 & 42 & 20 & 30 & 40 & 50 & 1.64 \\
\hline United Kingdom & $\mathrm{COM}$ & 12 & 67 & 33 & 46 & 41.77 & 79 & 2.59 \\
\hline Greece & CIV & 1 & 7 & 4 & 4 & 50 & 8 & 0.26 \\
\hline Hong Kong & $\mathrm{COM}$ & 0 & 29 & 12 & 17 & 41.38 & 29 & 0.95 \\
\hline India & $\mathrm{COM}$ & 0 & 48 & 16 & 32 & 33.33 & 48 & 1.57 \\
\hline Ireland & $\mathrm{COM}$ & 7 & 29 & 15 & 21 & 41.67 & 36 & 1.18 \\
\hline Israel & $\mathrm{COM}$ & 0 & 331 & 17 & 314 & 5.14 & 331 & 10.86 \\
\hline Italy & CIV & 0 & 23 & 2 & 21 & 8.70 & 23 & 0.75 \\
\hline Jersey & CIV & 1 & 13 & 2 & 12 & 14.29 & 14 & 0.46 \\
\hline Japan & $\mathrm{CIV}$ & 0 & 67 & 0 & 67 & 0 & 67 & 2.20 \\
\hline Korea & CIV & 0 & 30 & 3 & 27 & 10 & 30 & 0.98 \\
\hline Liberia & $\mathrm{COM}$ & 0 & 8 & 0 & 8 & 0 & 8 & 0.26 \\
\hline Luxembourg & $\mathrm{CIV}$ & 6 & 17 & 12 & 11 & 52.17 & 23 & 0.75 \\
\hline Mexico & CIV & 2 & 86 & 7 & 81 & 7.95 & 88 & 2.89 \\
\hline Marshall Islands & $\mathrm{COM}$ & 0 & 118 & 10 & 108 & 8.47 & 118 & 3.87 \\
\hline Netherlands & CIV & 0 & 50 & 8 & 42 & 16 & 50 & 1.64 \\
\hline Netherlands Antillen & $\mathrm{COM}$ & 0 & 8 & 0 & 8 & 0 & 8 & 0.26 \\
\hline Norway & CIV & 0 & 8 & 4 & 4 & 50 & 8 & 0.26 \\
\hline New Zealand & $\mathrm{COM}$ & 1 & 6 & 3 & 4 & 42.86 & 7 & 0.23 \\
\hline Panama & $\mathrm{CIV}$ & 0 & 7 & 2 & 5 & 28.57 & 7 & 0.23 \\
\hline Philippines & $\mathrm{COM}$ & 0 & 8 & 4 & 4 & 50 & 8 & 0.26 \\
\hline Russia & CIV & 0 & 22 & 1 & 21 & 4.55 & 22 & 0.72 \\
\hline Singapore & $\mathrm{COM}$ & 0 & 5 & 0 & 5 & 0 & 5 & 0.16 \\
\hline Turkey & CIV & 1 & 7 & 4 & 4 & 50 & 8 & 0.26 \\
\hline Taiwan & CIV & 0 & 40 & 0 & 40 & 0 & 40 & 1.31 \\
\hline \multirow[t]{2}{*}{ South Africa } & $\mathrm{COM}$ & 1 & 7 & 4 & 4 & 50 & 8 & 0.26 \\
\hline & & 73 & 2976 & 409 & 2640 & 15.49 & 3049 & 100.00 \\
\hline
\end{tabular}

Notes. CIV: Civil Law.

COM: Common Law. 


\section{Copyrights}

Copyright for this article is retained by the author(s), with first publication rights granted to the journal.

This is an open-access article distributed under the terms and conditions of the Creative Commons Attribution license (http://creativecommons.org/licenses/by/3.0/). 